\title{
Erratum to: Oxygen Transport to Tissue XXXVI
}

Harold M. Swartz, David K. Harrison, and Duane F. Bruley

Errata to: H.M. Swartz et al. (eds.), Oxygen Transport to Tissue $X X X V I$, Advances in Experimental Medicine and Biology 812, https://doi.org/10.1007/978-1-4939-0620-8

Chapters 22, 24, 25 and 26 were originally published (C) Springer Science+Business Media, LLC, but have now been made available (C) The Authors and open access under a CC BY 4.0 license.

The updated online versions of these chapters can be found at https://doi.org/10.1007/978-1-4939-0620-8_22 https://doi.org/10.1007/978-1-4939-0620-8_24 https://doi.org/10.1007/978-1-4939-0620-8_25

https://doi.org/10.1007/978-1-4939-0620-8_26

https://doi.org/10.1007/978-1-4939-0620-8 